\title{
Is there a market for partial corporate control? Evidence from REITs
}

\author{
Susanne Cannon, Rebel Cole* and Jonathan Dombrow \\ Department of Finance \\ DePaul University \\ Chicago, IL 60604 USA
}

\begin{abstract}
In October of 2002, the Simon Property Group made a hostile takeover bid for Taubman Centers, a bid that the financial press widely reported as the first significant hostile takeover attempt in the U.S. REIT industry. As such, this event provides a natural experiment for estimating the value of the market for corporate control, one of the primary corporate governance mechanisms by which the market ensures that firm managers maximize shareholder value. Contrary to our expectations, we find no significant industry price reaction in response to this announcement, strong evidence that this event did not mark the introduction of a market for corporate control into the REIT industry. We argue that REIT anti-takeover provisions had doomed Simon's bid from the start and continue to preclude operation of a market for corporate control. However, we do find that Taubman's shares responded favorably to the announcement, rising by 12 percent on the announcement day. We attribute this to operation of the market for partial corporate control as described by Bethel, Leibeskind and Opler (1998).
\end{abstract}

DRAFT: March 31, 2006

Do note quote without permission.

* Corresponding author. Phone: 312-362-6887 E-Mail: rcole@depaul.edu 


\section{Is there a market for partial corporate control? Evidence from REITs}

\section{Introduction}

In October of 2002, the Simon Property Group announced a bid for Taubman Centers, Inc., which the financial press reported as the first major hostile takeover attempted in the U.S. REIT industry. ${ }^{1}$ As such, this event provides a natural experiment for estimating the value of the market for corporate control, one of the primary corporate governance mechanisms by which the market ensures that firm managers maximize shareholder value. ${ }^{2}$ In this study, we estimate the changes in firm value associated with the introduction of this governance mechanism into the REIT market and then explore likely determinants of these changes in value. By limiting our analysis to the equity REIT industry, we effectively eliminate inter-industry heterogeneity.

${ }^{1}$ See PR Newswire and SNL Securities, Nov. 13, 2002; the Wall Street Journal, Nov. 20, 2002; and The National Real Estate Investor, May 1, 2003, among many others.

${ }^{2}$ Other primary corporate governance mechanisms include incentive compensation for firm managers, monitoring by large shareholders, monitoring by creditors, monitoring by the board of directors (especially by independent/outside directors), the managerial labor market, regulation, and legal protection. See Shleifer and Vishny (1998) for a survey of the corporate governance literature through the mid-1990s.

In the real estate literature, Cannon and Vogt (1994), Davis and Shellor (1995), Chopin, Dickens and Shellor (1995), Hardin (1998) Pennathur and Shellor (2002) examine determinants of REIT executive compensation. Friday, Sirmans and Conover (1998), Capozza and Seguin (2003), and Han (2006) examine ownership structure. Friday and Sirmans (1999) and Ghosh and Sirmans (2003, 2005) examine Board structure.

Several studies find evidence of rational contagion among financial institutions in response to firm-specific announcements about real-estate asset quality problems (Fenn and Cole (1994); Ghosh, Guttery and Sirmans $(1997,1998)$ ). Howe and Jain (2004) find significant crosssectional differences in the market reaction of REITs to the introduction in the House of Representatives of the REIT Modernization Act of 1999.

Allen and Sirmans (1987) were the first to analyze REIT takeovers, finding positive and significant abnormal returns for acquirers. They attributed these positive returns to improved management of the acquired assets. Using a different sample that included acquisitions of nonREITs, Elayan and Young (1994) find insignificant returns. Using a sample of 1994-98 mergers, Campbell, Ghosh and Sirmans (2003) find negative returns when targets are public but positive returns when targets are private. 
Prior to the Simon bid, industry observers had considered REITs immune to hostile takeovers because of their idiosyncratic structure. A potential investor seeking to consummate a hostile acquisition in the REIT industry faced an array of anti-takeover devices that included excess share provisions, staggered boards, and poison pills. REITs embraced these provisions under the cloak of protecting their trust's tax status as a REIT under the 5/50 rules ${ }^{3}$. Hence, investors attempting to coerce REIT managers (and controlling shareholders) to maximize the value of their shares were forced to do so via alternative corporate control mechanisms. (See footnote 2.)

The circumstances surrounding the Simon Property Group’s hostile takeover bid for Taubman Centers permit us to examine how the introduction of a "market for corporate control" affects firm value. We expect to find a significant positive reaction of equity REIT stocks to the Simon takeover announcement.

Contrary to our expectations, we find no significant industry price reaction in response to this announcement, strong evidence that this event did not mark the introduction of a market for corporate control into the REIT industry. We argue that REIT anti-takeover provisions had doomed Simon's bid from the start and continue to preclude operation of a market for corporate control. However, we do find that Taubman's shares responded favorably to the announcement, rising by 12 percent on the announcement day. This raises the obvious question: why did investors bid up Taubman's stock price if they knew that the hostile takeover bid was doomed to fail? We believe that the answer to this question lies in yet another corporate governance mechanism: the market for partial corporate control. Bethel, Leibeskind and Opler (1998, p. 606) first introduced this concept into the governance literature, arguing that "the purchase of

${ }^{3}$ Ghosh and Sirmans (2003) note that all previous acquisitions in the REIT industry had been accomplished on friendly terms. 
partial control blocks with the intent to influence corporate policy improves firm performance and creates shareholder value.” In other words, a takeover bid need not be successful to affect corporate policy and create shareholder value; it need only influence the actions of existing management to act in the interests of diffuse minority shareholders.

The remainder of the paper is organized as follows. In Section II, we review details of the Simon Company's bid for Taubman Centers and chronicle the timeline of the bid. In Section III, we briefly review the relevant literature on corporate governance. In section IV, we describe our data and methodology. Section V presents our results, followed in Section VI by a discussion of our findings for both individual REIT firms and the entire REIT industry in regards to corporate governance. Section VII provides a summary and conclusions.

\section{Details of Simon Property Group’s Proposed Takeover of Taubman Centers}

To date, there has not been a successful hostile takeover in the US REIT industry. The most closely related event was Westfield Corporation's takeover of Rodamco, where the Australian bidder acquired a Dutch target that owned a significant portfolio of U.S. retail real estate. Within the US REIT industry, the most frequently cited takeover event is an unsuccessful attempt in August of 1996 by Sam Zell's Manufactured Home Communities to acquire Chateau Properties. The Chateau board rejected Zell's offer as well as another unsolicited offer from Sun Communities, Inc., in favor of a merger with ROC Communities, Inc., thereby forming Chateau Communities, Inc. A lengthy battle ensued as two major stockholder lawsuits were filed and Chateau's three largest stockholders sold off their shares. In the end, the outcome was unchanged and the Chateau/ROC merger was consummated. 
Seven years later, in May 2003, Zell entered into negotiations to buy Chateau. Negotiations fell apart and Zell once again attempted a hostile takeover. In response, Chateau sought a white knight. The end result was a transaction with Hometown America that took Chateau private.

It is against this backdrop that the announcement of Simon's October 2002 hostile takeover bid drew such attention. The story really begins in 1998, when General Motors Pension Trust swapped out of its partnership interest with Taubman to gain direct ownership of ten malls. The Taubman family used this restructuring event to bolster its control of Taubman Centers by adopting dual-class shares; issuing approximately 32 million "Series B" shares to the family without seeking shareholder approval. These shares accounted for approximately one percent of the cash-flow right but approximately 30 percent of the control rights of the firm. Because one of Taubman Center's charter provisions requires a two-thirds vote of approval for any proposed takeover, these new "B" shares came close to giving the Taubman family veto power over any future proposed acquisition, greatly exacerbating problems arising from the separation of ownership and control.

Several years later, on October 22, 2002, David Simon of Simon Property Group, Inc. wrote to Robert S. Taubman, scion of the Taubman family, setting forth the basic terms of a purchase offer for Taubman Centers, Inc., a real estate investment trust that competed against the Simon REIT. This appeared to be an attractive and synergistic match since the Simon Group's assets consisted primarily of mid-scale suburban malls, whereas Taubman Centers’s holding were predominately upscale suburban malls. However, there were long-existing tensions between the two families that would play a critical role in the outcome of this event. 
After refusing a face-to-face meeting, Robert Taubman wrote back to Simon on October 28, stating that: "the Company has no interest whatsoever in pursuing a sale transaction..." All of this became public two weeks later, on November 13, with a press release and the release of a copy of Simon’s letter to Taubman proposing to purchase the shares outstanding for $\$ 17.50$ per share in cash. The $\$ 17.50$ offer included a premium of $18.2 \%$ over the previous day’s closing price, which brought the offer price over and above the highest level that Taubman Centers had ever previously traded.

Also transpiring on November 13th, David Simon wrote a letter to Taubman Center's board of directors, challenging it to act in the best interests of the public shareholders. Simon's message implied that the Taubman family was irrationally blocking an excellent deal for minority shareholders as well as for the family's controlling shares. The letter addressed the importance of good corporate governance and sought Taubman directors' "help in restoring the rights of the public shareholders of Taubman.” Simon also challenged the Taubman family's blocking position via the aforementioned adoption of dual class shares. In the letter, he questioned the propriety and validity of the transaction, which, he wrote, "attempts to transfer to the Taubman family control and a permanent veto over material decisions that rightfully belong to the public shareholders ...."

Over the next year, the battle between the two firms was waged in the press, the courtroom and even the Michigan legislature. During November of 2002, Simon made public the fact that the Taubman family only owned about $1 \%$ of the value of the firm's outstanding shares but these shares controlled over $30 \%$ of the votes, an egregious deviation from the corporate governance principal of one-share one-vote. By the time the story ended, the deadlines for 
tendering shares were extended, the offer price was raised twice, and the Michigan legislature passed a special bill legitimizing the questionable 1998 issuance of the "B" shares.

Michigan’s Governor Graham signed the special legislation on October 7, 2003, restoring the Taubman family's "B" shares' voting rights. The legislation effectively allowed the Taubman family to block the Simon Property Group’s ability to conclude its all-cash offer (joint with Westfield Corp.) for Taubman Centers' common stock, which, by the way, was supported by the overwhelming majority of Taubman's common shareholders.

On the next day, Simon and Westfield withdrew their \$20.00 all cash tender offer for all outstanding common shares of Taubman Centers. One week after that, Simon and Taubman mutually agreed to dismiss a lawsuit and a pending appeal regarding the bid.

According to Taubman's legal counsel, Taubman's successful takeover defense provided four lessons:

1. REIT and UPREIT governance structures provide adequate shareholder protection. In the Taubman case, the offer was too low and the Board was right. It's true that REITs and UPREITs can be mishandled as in any publicly traded company, but the structures do not in and of themselves lead to bad results.

2. An UPREIT governance structure like Taubman's are inherently fair and appropriate. It allows voice in accordance with economic interest and fundamental matters, like a sale, are not left to the majority vote of shareholders.

3. REITs' excess share ownership limitations generally provide legitimate and effective protection against both the loss of REIT qualification and abuse by raiders. 
4. Taubman's success does not prove that REITs or UPREITs are takeover proof. REITs are no less vulnerable to unsolicited takeovers than other public companies, and it is generally prudent for REITs to supplement their excess share provisions with a shareholder rights plan or "poison pill” in order to protect shareholder value.

Disinterested parties, corporate governance experts, as well as Taubman Center shareholders, would most likely take issue with Taubman’s counsel’s “lessons.”

\section{Background on the Market for Corporate Control}

The market for corporate control is one of the primary corporate governance mechanisms by which investors ensure that firm managers act to maximize shareholder value rather than manager’s utility. In their survey of the corporate governance literature, Shleifer and Vishny (1997, p. 756) write "Takeovers are widely interpreted as the critical corporate governance mechanism in the United States, without which managerial discretion cannot be effectively controlled.”

Interestingly, Shleifer and Vishny point out that "hostile takeovers are politically an extremely vulnerable mechanism, since they are opposed by managerial lobbies.” The actions of the Michigan legislature and Governor documented in Section II underscore the accuracy of this observation.

Incumbent managers typically lose their job after a takeover (Martin and McConnell (1991)). Consequently, incumbent managers often actively oppose takeover attempts,

irrespective of shareholders' interests. Weapons available in management's arsenal are quite varied and include dual class shares, poison pills, staggered boards, and issuance of debt. 
Dual-class shares involve the issuance of a second class of shares that have voting rights in excess of their cash-flow rights, increasing the wedge between cash-flow rights and control rights. Such shares enable a shareholder to control a firm with significantly less than a majority of shares. (See DeAngelo and DeAngelo (1985) for a study of corporations that issue dual-class shares.)

A poison pill (also known as a "shareholder rights plan") is a security, typically issued as a dividend, than entitles the bearer to purchase additional shares in the event that one investor obtains ownership beyond some trigger level without permission of the board of directors. (See Bruner (1991) for a detailed description of the mechanics of the poison pill.) A pill greatly increases the costs of a hostile takeover. Comment and Schwert (1995, p.4) write that a pill "create(s) impossibly burdensome obligations for anyone who buys a controlling block of shares without management approval.”

A staggered (or "classified") board is a charter provision than mandates "classes" of directors staggered across two or more years. Such a board structure requires any hostile bidder to win at least two consecutive board elections at annual meetings, forcing the bidder to keep her offer open for at least one full year.

Gompers, Ishii and Metrick (2003) explore the correlation between extent of shareholder rights and returns. His findings suggest there is a strong positive correlation, meaning that weaker shareholder rights are associated with lower profits, lower sales growth, higher cap ex, etc. The strongest shareholder rights are consistent with highest returns.

Bebchuk, Coates, and Subramanian (2002) argue that takeovers increase shareholder returns by $8-10 \%$ and that anti-takeover devices, such as staggered boards, are harmful to shareholders. Separately, Bebchuk (2004) observes that strong anti-takeover protections decrease 
share value by five percent and present a moral hazard to management in that they are not as careful and have poorer operating performance.

Several studies have narrowed their focus to boards of directors. Stout (2003) defines the purpose of a board as mediation "between the firm's shareholders and other important constituencies that make extra-contractual specific investments in the firm. What's more, shareholders favor this arrangement.” Gordon (2002) argues that anti-takeover provisions enable boards to raise bid prices in takeover situations and ensure a long-term vision for the company.

On the other hand, Bebchuk and Hart (2004) argue that proxy battles provide evidence that board members and shareholder interests are not aligned. Bebchuk and Cohen (2003) point out that staggered boards are associated with reduction in firm value. Moreover, Bebchuk, Coates and Subramanian (2002) provide strong evidence that the combination of a staggered board and poison pill almost completely eliminates the possibility of a successful hostile takeover. Hence, firms employing these anti-takeover devices should benefit less than firms without such provisions when a market for corporate control is introduced.

Berger, Ofek and Yermack (1997) and Garvey and Hanka (1999) provide evidence consistent with theories (Zwiebel (1996), Novaes and Zingales (1995)) that takeover targets use leverage as an anti-takeover device. Hence, firms with less leverage should be more susceptible to a hostile bid and, therefore, should disproportionately benefit from the introduction of a market for corporate control.

Several studies have documented that takeover targets tend to be poorly performing firms. (Palepu (1985), Morck, Shleifer and Vishny (1988, 1989). Hence, poorly performing firms would be expected to disproportionately benefit from the introduction of a market for corporate control. 


\section{Data and Methodology}

\section{A. Data}

Our data include daily stock return data, accounting data, ownership data and data on corporate charter/bylaw provisions. We obtain daily stock return data for 2001-2002 from the Center for Research in Securities Prices (CRSP). Our accounting data include a variety of balance-sheet and income statement data for 2002, and were obtained from SNL Securities. Our ownership data also were obtained from SNL Securities and includes the percentage stock ownership by inside and outside block holders. Our information on firm charters and bylaws includes information on whether or not firms have staggered boards and/or poison pill provisions in their charters and/or bylaws, and were provided by the Investor Responsibility Research Center (IRCC).

Table 1 presents descriptive statistics for our data separated into Governance Variables and Financial Variables.

\section{Governance Variables}

On average, our sample firms have combined insider block ownership of 13.6 percent, with a range of $1.6 \%$ to $75.0 \%$. Outsider block ownership averages $54.9 \%$, with a range of $0.2 \%$ to $90.0 \%$. Forty percent of our sample firms have adopted poison pills; 64.8 percent have adopted staggered boards.

\section{Financial Variables}

On average, our firms have $\$ 2.522$ billion in total assets and $\$ 1.424$ billion in market capitalization as of year-end 2002. There is wide variation in both measures. The smallest firm 
by assets is only $\$ 66$ million whereas the largest is $\$ 25.707$ billion. Market cap ranges from $\$ 25$ million to $\$ 12.114$ billion.

We measure firm performance using the ratio of Funds From Operations (FFO) to total assets, the REIT industry's equivalent to ROA. On average, our firms earned 170 basis points, with a range of -62 to 437 .

We examine the REIT industry equivalent to the P/E ratio, using the ratio of price to FFO. This ratio, which measures how much an investor is willing to pay for $\$ 1.00$ of earnings (as measured by FFO) averages 9.84, with a range of 2.40 to 16.60 . High P/Es typically are interpreted as indicating firms with high prospects for growth. We also examine growth explicitly using the growth rate of FFO per share. For our sample, the average growth rate of FFO per share is -1.8 percent, with a range of -50 percent to 102.7 percent.

We also analyze the REIT industry equivalent of the market-to-book ratio, measured by the ratio of market price per share to Net Asset Value (NAV) per share. NAV is calculated by SNL as a combination of $i$ ) the capitalization of net operating income using a discount rate of nine percent, being added to ii) a summation of several of a firm's asset categories. For our sample, the ratio of price to NAV averages 1.08 with a range of 0.33 to 2.34 .

Finally, we measure leverage by the ratio of total debt to total assets. On average, our firms have a debt-to-asset ratio of 0.422 , with a range of zero to 0.712 .

In summary, we find wide variation in the financial ratios of our firms, especially with respect to leverage and earnings. Consequently, we expect that poorly performing firms and firms with low leverage should disproportionately benefit from the introduction of a market for corporate control into the REIT industry. 


\section{B. Methodology}

\section{Industry-Portfolio Cumulative Abnormal Returns}

To test the overall industry impact of the corporate control announcement, we form an equally weighted portfolio of all sample firms and analyze the cumulative abnormal returns around the announcement date. We use a three-day event window that includes the day before, the day of and the day after the announcement. We estimate a model that includes the contemporaneous return on the CRSP equal- or value-weighted index.

$$
\text { Portfolio Return }_{t}=\beta_{0}+\beta_{1} \text { Event Dummy }+\beta_{2} \text { Market Return }_{t}+\varepsilon_{t}
$$

where:

Portfolio Return ${ }_{t}$ is the return for day $t$ on a portfolio of equity REITs;

Market Return ${ }_{t}$ is the return for day $t$ on the CRSP equal- or value-weighted market portfolio;

Event Dummy is a dummy variable that equals $1 / \mathrm{n}$ for the dates within the event window of length $n$ days; ${ }^{4}$

$\beta_{2}$ is the estimated cumulative abnormal return associated with the event window; and $\varepsilon_{t}$ is an i.i.d. random-error term for day $t$.

\footnotetext{
${ }^{4}$ We define the event-dummy variable as equal to $1 / n$, where $n$ is the length of the event window, so that the coefficient on our dummy variable measures the total cumulative abnormal return over the entire event window. Were we to define the dummy variable as equal to 1 within the event window, then the coefficient would instead measure the average daily abnormal return during the event window.
} 
We estimate each model over a period of 500 trading days that begins January 2, 2001 and ends December 31, 2002.

\section{Cross-Sectional Differences in Cumulative Abnormal Returns}

In addition to testing industry-wide changes in value attributable to the introduction of a market for corporate control, we also test whether this event had a differential impact on firms with different characteristics. This process involves two steps. First, we must estimate firmspecific cumulative abnormal returns. Second, we estimate the cross-sectional relationship between these firm-specific cumulative abnormal returns and a set of firm-specific explanatory variables.

Step One:

To estimate the cumulative abnormal return for each firm, we re-estimate eq. (1) for each firm over the same 500-day period that we use to estimate the portfolio cumulative abnormal return, where, as before, we include a dummy variable for the event window:

Firm Return $_{i, t}=\beta_{0, i}+\beta_{1, i}$ Event Window $+\beta_{2, i} *$ Market Return $_{t}+\varepsilon_{i, t}$

where:

Firm Return ${ }_{i, t}$ is the return for firm $i$ on day $t$;

$\beta_{1, i}$, is the cumulative abnormal return (CAR) for firm $i$ during the event window;

Market Return ${ }_{t}$, Event Window and are defined as above for eq. (1); and

$\varepsilon_{i, t}$ is an i.i.d random-error term for firm $i$ on day $t$. 
To control for heteroscedasticity, we follow Naranjo et al. (2000) and use weighted-least-squares regression to explain the abnormal returns, where the inverses of the standard deviations of the prediction errors derived from the market model are used as weights.

Step Two:

To test whether firms with certain characteristics disproportionately benefit from the introduction of a market for corporate control, we use the following cross-sectional regression model:

$$
C A R_{i}=\gamma_{0}+\gamma_{i} X_{i}+\varepsilon_{i}
$$

where:

$C A R_{i}$ is the cumulative abnormal return for firm $i$ estimated as $\beta_{1, i}$,using eq. (2) above;

$X_{i}$ is a vector explanatory variables for firm $i$;

$\gamma_{i}$ is a vector of parameter estimates for the vector of explanatory variables $X_{i}$; and $\varepsilon_{i}$ is an i.i.d random-error term for firm $i$.

As noted in Section III, we expect that firms with certain characteristics would be expected to disproportionately benefit from the introduction of a market for corporate control. The specific variables we test are:

Firm Size: We hypothesize that large firms disproportionately benefit relative to small firms for a number of reasons. At large firms there are more assets to expropriate, and the same level of expropriation is easier to hide at a large firm. Large firms are more complex and difficult to manage, hence it is more likely that a large firm is mismanaged relative to a small firm. Finally, large firms are thought to suffer from more severe agency problems than small firms for at least 
two reasons. First, insider ownership is lower at larger firms. Second, managers face strong incentives to increase firm size because size has been found to be the primary determinant of executive compensation (Jensen and Murphy 1990). We measure firm size using the natural log of market capitalization.

Insider Block Ownership: We hypothesize that firms with lower insider ownership disproportionately benefit relative to firms with higher levels of insider ownership. For a widely held firm, the lower the insider ownership, the greater is the separation of ownership and control (Jensen and Meckling (1976)). Managers who own a greater portion of the firm's shares have less incentive to expropriate because they receive a smaller gain from expropriation than do managers with lower ownership. For a firm with a controlling shareholder, a situation very common at REITs, a similar relationship exists. Firms with greater wedges between cash-flow rights and control rights will face a greater incentive to expropriate minority shareholders. Morck, Shleifer and Vishny (1989) provide evidence that this relationship is nonlinear. Consequently, we also test for nonlinearity by including a squared term and by using a piecewise measure of insider ownership as well.

Outsider Block Ownership: We hypothesize that firms' lower levels of outsider ownership disproportionately benefit relative to firms with greater levels of outsider ownership. The greater the outsider block ownership of a firm, the greater is both the outside block holder(s)' incentive to monitor firm managers as well as for controlling shareholders to guard against expropriation of the value of their shares.

Monitoring by non-management block holders has widely been recognized as an important corporate control mechanism (Shleifer and Vishny (1986); Bethel, Liebeskind and Opler (1998)). 
Firm Performance: Investors are most likely to target poorly performing firms as takeover candidates because such firms offer the greatest potential returns from a change in management. (Palepu (1985), Morck, Shleifer and Vishny $(1988,1989)$. The very purpose of the market for corporate control is to discipline poorly performing managers by replacing them with new managers who can better maximize shareholder value. Note that poor performance can result either from honest but incompetent management or from competent management coupled with expropriation of shareholder wealth by firm management and/or controlling shareholders.

We use two proxies for firm performance that are peculiar to the REIT industry: the ratio of FFO to assets and the ratio of price to NAV. As noted previously, the former is analogous to ROA while the latter is analogous to a price-to-book ratio. Numerous studies have used the market-to-book ratio as measures of firm performance, where higher ratios are interpreted as indicative of better performance. Several studies in the corporate governance literature have documented that firms with poor governance are penalized with lower ratios of market-to-book (see, e.g., La Porta et al. (2002)). Hence, we expect that REITs with poor governance should have lower values of price to NAV, and should disproportionately benefit from introduction of a market for corporate control.

In addition to the cross-sectional regression, we will use a portfolio time-series regression to test the relation between abnormal returns and the quality of corporate governance. The portfolio time-series regression is designed to deal with econometric problems that arise when there is cross-correlation in the firm return processes from which the CARs are estimated. Cross-correlation is likely because, for each event, the event date and event windows are identical across sample firms. The portfolio time-series regression provides unbiased estimates of 
the coefficients along with standard errors that fully account for cross-sectional heteroscedasticity and cross-security dependence (see Sefcik and Thompson (1986). ${ }^{5}$ )

\section{Results}

\section{A. Industry-wide Cumulative Abnormal Returns}

Results from estimating portfolio cumulative abnormal returns using eq. (1) appear in Table 2. Separate results are presented for coefficients estimated using the mean-adjusted return model (column 2), the market model using an equal-weighted market index (column 3) and the market model using a value-weighted market index. The cumulative abnormal return for the three-day event window is the coefficient for the dummy variable Event Window. For the meanadjusted return model, the estimated CAR is 1.84 percent; for the market model using an equalweighed market index, the estimated CAR is 0.64 percent; for the market model using a valueweighted index, the estimated CAR is 0.69 percent. While each of this is positive as hypothesized, none are statistically or economically significant. However, industry-wide results may obscure significant results for portfolios of firms with the industry based upon specific firm performance and governance characteristics, as described above in Section IV. Consequently, we next test for such significant differences.

\footnotetext{
${ }^{5}$ The problems of heteroscedasticity and cross-sectional dependence also can, in principle, be addressed in a generalized-least-squares (GLS) regression. Several studies, however, show that GLS tests are highly sensitive to errors in specifying the abnormal return model. (See, for example, Chandra and Balachandran 1990.) Grammatikos and Saunders (1990) apply the Sefcik and Thompson methodology to study the effect of bank loan-loss reserve announcements on bank stock returns. Forbes (2000) uses the Sefcik and Thompson methodology to study the international transmission of financial crises at the firm level.
} 


\section{B. Cross-Sectional Difference in Firm Cumulative Abnormal Returns}

To analyze cross-sectional difference in firm CARs, we first must estimate CARs on a firm-by-firm basis. We use eq. (2) to estimate these CARs. On average, the results are similar in magnitude to those appearing in Table 2. However, parametric and nonparametric tests for statistical significance indicate that average CARs are significant at better than the one percent level. However, these CARs remain of questionable economic significance.

The second step in estimating cross-sectional differences in CARs is to regress the firmspecific CARs estimated using eq. (2) against a vector of firm governance and financial characteristics, as shown in eq. (3), using a weighting of the inverse of the standard error of the market-model prediction error. The results of this procedure appear in Table 3. In column 2 are results from including only the governance variables; in column 3 are results from including only the financial variables; and, in column 4 are the results from including both sets of variables.

\section{Governance Variables}

As shown in Column 2 of Table 3, each of the five governance variables has the expected sign, with the dummy indicator for staggered boards being the exception. CARs are lower for firms with higher levels of both insider block ownership and outsider block ownership and for firms that have adopted poison pills. CARs are higher for larger firms. However, none of the variables are statistically significant at even the ten percent level.

\section{Financial Variables}

As shown in Column 3 of Table 3, the ratio of FFO to assets is positive and significant at the five percent level, indicating that CARs are higher for better performing REITs. The ratio of price to FFO also is positive and significant at the five percent level, indicating that CARs are 
higher for high P/E REITs. These results are contrary to our hypothesis that poorly performing firms are the most likely takeover candidates and therefore should disproportionately benefit from introduction of a market for corporate control. This result suggests that it is better performing firms that are the most likely takeover candidates in the REIT industry. The remaining three financial variables, FFO per share growth, the ratio of debt to assets and the ratio of price to NAV, lack statistical significance

\section{Governance and Financial Variables}

As shown in Column 4 of Table 4, the results from including both the governance and financial variables are not qualitatively different from the results obtained estimating each group separately. As above, only two of the ten variables are statistically significant: the ratio of FFO to assets and the ratio of price to FFO. None of the remaining eight variables is significant at the 10 percent level.

\section{Conclusions}

The October 2002 hostile takeover bid by the Simon Property Group for Taubman Centers was the first significant hostile takeover attempt in the REIT industry. As such, this event provides a natural experiment for estimating the value of the market for corporate control. In this study, we estimate the changes in firm value associated with the introduction of this governance mechanism into the REIT market.

Contrary to our expectations, we find no significant industry price reaction in response to this announcement, strong evidence that this event did not mark the introduction of a market for corporate control into the REIT industry. We argue that REIT anti-takeover provisions had 
doomed Simon's bid from the start and continue to preclude operation of a market for corporate control. However, we do find that Taubman's shares responded favorably to the announcement, rising by 12 percent on the announcement day. This raises the obvious question: why did investors bid up Taubman's stock price if they knew that the hostile takeover bid was doomed to fail? We believe that the answer to this question lies in yet another corporate governance mechanism: the market for partial corporate control. Bethel, Leibeskind and Opler (1998, p. 606) first introduced this concept into the governance literature, arguing that "the purchase of partial control blocks with the intent to influence corporate policy improves firm performance and creates shareholder value.” In other words, a takeover bid need not be successful to affect corporate policy and create shareholder value; it need only influence the actions of existing management to act in the interests of diffuse minority shareholders. 


\section{References}

Allen, P., and Sirmans, C.F. 1987. “An analysis of gains to acquiring firm's shareholders: The special case of REITs.” Journal of Financial Economics 18, 74-184.

Bebchuk, L. 2004. “The Case for Increasing Shareholder Power.” Harvard University working paper.

Bebchuk, L., Coates, J., and Subramanian, G. 2002. “The Powerful Antitakeover Force of Staggered Boards: Theory, Evidence and Policy.” Stanford Law Review, 54, 887.

Bebchuk, L, and Hart, O. 2004. “Takeover Bids vs. Proxy Fights in Contests for Corporate Control.” Harvard University working paper.

Bebchuk, L., and Cohen, A. 2003. “The Costs of Entrenched Boards.” Harvard University working paper.

Berger, P., Ofek, E., and Yermack, D. 1997. "Managerial Entrenchment and Capital Structure Decisions.” Journal of Finance, 52, 1411.

Bethel, J., Liebeskind, J., and Opler, T. 1998. "Block Share Purchases and Corporate Performance.“ Journal of Finance, 53, 695.

Bruner, R. 1991. “The Poison Pill Antitakeover Defense: The Price of Strategic Deterrences.” The Institute of Chartered Financial Analysts (Charlottesville, VA)

Cannon, S., and Vogt, S. 1995. "REITs and Their Management: An Analysis of Organizational Structure, Performance and Management Compensation.” Journal of Real Estate Research 10, 297-317.

Capozza, D., Seguin, P. 2003. “Inside Ownership, Risk Sharing and Tobin’s q-Ratios: Evidence from REITs.” Real Estate Economics 31, 367-404.

Chandra, R., and Balachandran, B. 1990. "A Synthesis for Alternative Testing Procedures for Event Studies.” Contemporary Accounting Research, 611.

Chopin, M., Dickens, R,. and Shellor, R. 1995. “An Empirical Examination of Compensation of REIT Managers.” Journal of Real Estate Research 10, 263-277.

Comment, R., and Schwert, G. W.. 1995. "Poison or Placebo? Evidence on the Deterrent and Wealth Effects of Modern Antitakeover Measures.” Journal of Financial Economics, 39, 4.

Davis, B., and Shellor, R. 1995. "Executive Compensation and Financial Performance in the Real Estate Industry.” Journal of Real Estate Research 10, 141-151. 
DeAngelo, H., and DeAngelo, L. 1985. "Managerial Ownership of Voting Rights.” Journal of Financial Economics 14, 33.

Elayan, F., and Young, P. 1994. "The Value of Control: Evidence from Full and Partial Acquisitions in the Real Estate Industry.” Journal of Real Estate Finance and Economics 8, 167182.

Fenn, G., and Cole, R., 1994. "Announcements of asset-quality problems and contagion effects in the life insurance industry” Journal of Financial Economics 35, 181-198.

Forbes, K. 2000 "The Asian Flu and Russian Virus: Firm Level Evidence on How Crises are Transmitted internationally.” NBER Working Paper W7807.

Friday, S., Sirmans, G.S., and Conover, C. 1999. "Ownership Structure and the Value of the Firm: The Case of REITs.” Journal of Real Estate Research 17, 71-90.

Friday, S., and Sirmans, G.S., 1998. "Board of director monitoring and firm value in REITs." Journal of Real Estate Research 16, 411-427.

Garvey, G., and Hanka, G. 1999. "Capital Structure and Corporate Control: The Effect of Antitakeover Statutes on Firm Leverage.” Journal of Finance 54, 519.

Ghosh, C., and Sirmans, C.F. 2003. "Board Independence, Ownership Structure and Performance: Evidence from Real Estate Investment Trusts." Journal of Real Estate Finance and Economics 26, 287-318.

Ghosh, C., and Sirmans, C.F. 2005. "On REIT CEO Compensation: Does Board Structure Matter?” Journal of Real Estate Finance and Economics 30, 397-428.

Gompers, P., Ishii, J., and Metrick, A. 2003. "Corporate Governance and Equity Prices.” Quarterly Journal of Economics 118, 107.

Gordon, M. 2002. "Takeover Defenses Work. Is that such a bad thing?" Stanford Law Review

Grammatikos, T., and Saunders, A. 1990. "Additions to Bank Loan Loss Reserves: Good News or Bad News.” Journal of Monetary Economics 25, 289.

Howe, J., and Jain, R. 2004. “The REIT Modernization Act of 1999.” Journal of Real Estate Finance and Economics 28, 369-388.

Jensen, M. and Murphy, K. 1990. "Performance Pay and Top-Management Incentives.” Journal of Political Economy 98, 225.

Jensen, M., and Meckling, W. 1976. "Theory of the Firm: Managerial Behavior, Agency Costs, and Ownership Structure.” Journal of Financial Economics 3, 305. 
La Porta, R., Lopez-De-Salinas, F., Shleifer, A., and Vishny, R. 2002. "Investor Protection and Corporate Valuation.” Journal of Finance 57, 1147.

Martin, K., and McConnell, J. 1991. “Corporate Performance, Corporate Takeovers, and Management Turnover.” Journal of Finance 46, 671.

Morck, R., Shleifer, A., and Vishny, R. 1988. "Characteristics of Targets of Hostile and Friendly Takeovers.” Corporate Takeovers: Causes and Consequences

Morck, R., Shleifer, A., and Vishny, R. 1989. “Alternative Mechanisms of Corporate Control.” American Economic Review 79, 842.

Naranjo, A., Nimalendran, M., and Ryngaert, M. 2000. “Time Variation of Ex-Dividend Day Stock Returns and Corporate Dividend Capture: Re-Examination.” Journal of Finance 55, 2357.

Novaes, W., and Zingales, L. 1995. "Capital Structure Choice When Managers Are in Control: Entrenchment versus Efficiency.” NBER Working Paper 5384.

Palepu, K. 1985. "Predicting Takeover Targets: A Methodological and Empirical Analysis.” Journal of Accounting and Economics 8, 3.

Pennathur, A. K., and Shellor, R. 2002. “The Determinants of REIT CEO Compensation.” Journal of Real Estate Finance and Economics 25, 99-113.

Sefcik, S. and Thompson, R. 1986. “An Approach to Statistical inference in Cross-Sectional Models with Security Abnormal Returns as Dependent Variable.” Journal of Accounting Research 24, 316.

Shleifer, A., and Vishny, R.. 1986. “Large Shareholders and Corporate Control.” Journal of Political Economy 94, 461.

Shleifer, A., and Vishny, R. 1998. “A Survey of Corporate Governance.” Journal of Finance 52, 737

Zwiebel, J. 1996. “A Dynamic Capital Structure Under Management Entrenchment.” American Economic Review 86, 1197. 


\section{Table 1 \\ Descriptive Statistics}

The sample consists of 83 equity REITs that appear in the Morgan-Stanley REIT index and for which financial data are available from SNL securities. For each variable identified in column 1 , we present the mean in column 2 , the standard error in column 3 the minimum value in column 4 and the maximum value in column 5 .

\begin{tabular}{|c|c|c|c|c|}
\hline Variable & Mean & $\begin{array}{c}\text { Standard } \\
\text { Error }\end{array}$ & Minimum & Maximum \\
\hline \multicolumn{5}{|l|}{ Governance Variables } \\
\hline Insider Block Ownership & 0.136 & .012 & 0.016 & 0.750 \\
\hline Outsider Block Ownership & 0.549 & 0.023 & 0.002 & 0.900 \\
\hline $\begin{array}{l}\text { Poison Pill } \\
(\text { yes }=1, \text { no }=0)\end{array}$ & 0.40 & 0.048 & 0 & 1 \\
\hline $\begin{array}{l}\text { Staggered Board } \\
(\text { yes }=1, \text { no }=0)\end{array}$ & 0.648 & 0.047 & 0 & 1 \\
\hline $\begin{array}{l}\text { Operating Partnership Units } \\
(\text { yes }=1, \text { no }=0)\end{array}$ & 0.674 & 0.471 & 0 & 1 \\
\hline \multicolumn{5}{|l|}{ Financial Variables } \\
\hline $\begin{array}{l}\text { Total Assets } \\
\text { (\$Millions) }\end{array}$ & 2,522 & 314 & 66 & 25,707 \\
\hline $\begin{array}{l}\text { Market Capitalization } \\
\text { (\$Millions) }\end{array}$ & 1,424 & 164 & 25 & 12,114 \\
\hline FFO to Assets & 0.017 & 0.001 & -0.0062 & 0.0437 \\
\hline Debt to Assets & 0.422 & 0.014 & 0.000 & 0.712 \\
\hline Price to NAV per Share @9\% & 1.08 & 0.040 & 0.330 & 2.34 \\
\hline FFO per share Growth & -0.018 & 0.020 & -0.500 & 1.027 \\
\hline Price to FFO & 9.84 & 0.217 & 2.40 & 16.60 \\
\hline & & & & \\
\hline
\end{tabular}




\begin{tabular}{|c|c|c|c|}
\hline Cumulative Abno & al Returns aroı & $\begin{array}{l}\text { le } 2 \\
\text { inouncement of } 1\end{array}$ & ostile Takeover Bid \\
\hline $\begin{array}{l}\text { This table reports c } \\
\text { announcement that } \\
\text { To test the overall i } \\
\text { equally weighted p } \\
\text { REIT index and for } \\
\text { the cumulative abn } \\
\text { window that includ } \\
\text { estimate three mod } \\
\text { includes the contem } \\
\text { and a market mode } \\
\text { weighted index (co }\end{array}$ & $\begin{array}{l}\text { ulative abnormal } \\
\text { was making a hos } \\
\text { ustry impact of th } \\
\text { folio of 83ample } \\
\text { hich financial dat } \\
\text { al returns aroun } \\
\text { the day before, th } \\
\text { a mean adjusted } \\
\text { raneous return o } \\
\text { at includes the cc } \\
\text { an 4). We estima }\end{array}$ & $\begin{array}{l}\text { Is around The Sin } \\
\text { keover bid for the } \\
\text { orate control ann } \\
\text { REITs that appea } \\
\text { ivailable from SN } \\
\text { nnouncement date } \\
\text { of and the day aft } \\
\text { model (column } 2 \\
\text { RSP equally wei } \\
\text { qoraneous return c } \\
\text { quation of the for }\end{array}$ & $\begin{array}{l}\text { mpany’s } \\
\text { man company. } \\
\text { ment, we form an } \\
\text { e Morgan-Stanley } \\
\text { urities. We analyze } \\
\text { g a three-day event } \\
\text { announcement. We } \\
\text { narket model that } \\
\text { index (column 3) } \\
\text { CRSP value- }\end{array}$ \\
\hline $\begin{array}{l}\text { Portfolio Return } \\
\text { where: Portfolio Re } \\
\text { Return }{ }_{t} \text { is the retur } \\
\text { Dummy is a dumm } \\
\text { length n days; } \beta_{2} \text { is } \\
\text { window; and } \varepsilon_{t} \text { is a } \\
500 \text { trading days th } \\
\text { appear in parenthes } \\
\text { a indicates statistic } \\
\text { b indicates statistic } \\
\text { c indicates statistic }\end{array}$ & $\begin{array}{l}=\beta_{0}+\beta_{l} \text { Eve } \\
n{ }_{t} \text { is the return } \\
\text { or day t on the CI } \\
\text { ariable that equa } \\
\text { e estimated cumı } \\
\text { i.d. random-erro } \\
\text { pegins January 2, } \\
\text { under coefficient } \\
\text { ignificance at the } \\
\text { ignificance at the } \\
\text { ignificance at the }\end{array}$ & $\begin{array}{l}\text { amy }+\beta_{2} \text { Marke } \\
\text { t on a portfolio o } \\
\text { qually weighted m } \\
\text { or the dates withir } \\
\text { abnormal return a } \\
\text { We estimate eac } \\
\text { and ends Decemb } \\
\text { ates. } \\
\text { ercent level. } \\
\text { ercent level. } \\
\text { ercent level. }\end{array}$ & $\begin{array}{l}u r n_{t}+\varepsilon_{t} \\
\text { ity REITs; Market } \\
\text { portfolio; Event } \\
\text { event window of } \\
\text { ated with the event } \\
\text { lel over a period of } \\
\text { 2002. } t \text {-statistics }\end{array}$ \\
\hline & $\begin{array}{l}\text { Mean-Adjusted } \\
\text { Return Model }\end{array}$ & $\begin{array}{l}\text { Market Model, } \\
\text { Equal Weighted }\end{array}$ & $\begin{array}{l}\text { Market Model, } \\
\text { Value Weighted }\end{array}$ \\
\hline Intercept & $\begin{array}{c}0.0006 \text { c } \\
(1.78) \\
\end{array}$ & $\begin{array}{c}0.0004 \\
(1.44) \\
\end{array}$ & $\begin{array}{c}0.0008 \mathrm{a} \\
(3.06)\end{array}$ \\
\hline $\begin{array}{l}\text { Market } \\
\text { Index }\end{array}$ & & $\begin{array}{c}0.481 \\
(19.33)\end{array}$ & $\begin{array}{l}0.339 \text { a } \\
(17.81)\end{array}$ \\
\hline $\begin{array}{l}\text { Event Dummy } \\
\text { (CAR) }\end{array}$ & $\begin{array}{c}0.0184 \\
(1.36) \\
\end{array}$ & $\begin{array}{c}0.0064 \\
(0.63) \\
\end{array}$ & $\begin{array}{c}0.0069 \\
(0.65) \\
\end{array}$ \\
\hline Adjusted R-square & 0.002 & 0.431 & 0.391 \\
\hline
\end{tabular}




\begin{tabular}{|c|c|c|c|}
\hline Det & nts of $\mathrm{Cu}$ & bnormal R & \\
\hline $\begin{array}{l}\text { This table reports the re } \\
\text { explain cumulative abn } \\
\text { least-squares regression } \\
\text { cumulative abnormal re } \\
\text { Simon Property Group' } \\
\text { standard deviations of } \mathrm{t} \\
t \text {-statistics appear in par } \\
\text { only the governance va } \\
\text { column (4) we include } \\
\text { b indicates statistica } \\
\text { c indicates statistica }\end{array}$ & $\begin{array}{l}\text { om estime } \\
\text { eturns for } \\
\text { to regres } \\
\text { f individu } \\
\text { e-takeove } \\
\text { iction err } \\
\text { s under c } \\
\text { In colum } \\
\text { vernance } \\
\text { icance at } \\
\text { icance at }\end{array}$ & $\begin{array}{l}\text {-sectional re } \\
\text { 83ample fir } \\
\text { and financ } \\
\text { und the anr } \\
\text { Taubman c } \\
\text { rom the ma } \\
\text { timates. In } \\
\text { clude only t } \\
\text { l variables. } \\
\text { ent level. } \\
\text { nt level. }\end{array}$ & $\begin{array}{l}\text { lodel to } \\
\text { e a weighted- } \\
\text { es on } \\
\text { ts of the } \\
\text { We use the } \\
\text { as weights. } \\
\text {, we include } \\
\text { l variables. In }\end{array}$ \\
\hline$(1)$ & (2) & (3) & (4) \\
\hline Intercept & $\begin{array}{l}-0.006 \\
(-0.35)\end{array}$ & $\begin{array}{l}-0.025 \\
(-1.47)\end{array}$ & $\begin{array}{l}-0.043 \\
(-1.60)\end{array}$ \\
\hline Governance Variables & & & \\
\hline log of Market Cap & $\begin{array}{l}0.004 \\
(1.45)\end{array}$ & & $\begin{array}{l}0.002 \\
(0.61)\end{array}$ \\
\hline $\begin{array}{l}\text { Insider Block } \\
\text { Ownership }\end{array}$ & $\begin{array}{l}-0.009 \\
(-0.43)\end{array}$ & & $\begin{array}{l}-0.001 \\
(-0.43)\end{array}$ \\
\hline $\begin{array}{l}\text { Outsider Block } \\
\text { Ownership }\end{array}$ & $\begin{array}{l}-0.016 \\
(-1.39)\end{array}$ & & $\begin{array}{l}-0.011 \\
(-0.89)\end{array}$ \\
\hline Poison Pill & $\begin{array}{l}-0.006 \\
(-1.44)\end{array}$ & & $\begin{array}{l}-0.003 \\
(-0.69)\end{array}$ \\
\hline Staggered Board & $\begin{array}{l}0.006 \\
(1.23)\end{array}$ & & $\begin{array}{l}0.010 \mathrm{c} \\
(1.92)\end{array}$ \\
\hline $\begin{array}{l}\text { Operating Partnership } \\
\text { Units }\end{array}$ & $\begin{array}{l}-0.0007 \\
(-0.14)\end{array}$ & & $\begin{array}{l}0.005 \\
(0.99)\end{array}$ \\
\hline Financial Variables & & & \\
\hline FFO to Assets & & $\begin{array}{c}0.888 \mathrm{~b} \\
(1.98)\end{array}$ & $\begin{array}{l}1.005 \mathrm{~b} \\
(2.10)\end{array}$ \\
\hline Debt to Assets & & $\begin{array}{c}-0.00008 \\
(-0.46)\end{array}$ & $\begin{array}{c}-0.0001 \\
(-0.53)\end{array}$ \\
\hline Price to NAV@9.0\% & & $\begin{array}{c}-0.000001 \\
(-0.10)\end{array}$ & $\begin{array}{c}-0.00001 \\
(-0.24)\end{array}$ \\
\hline FFO per share Growth & & $\begin{array}{c}0.0001 \\
(0.81)\end{array}$ & $\begin{array}{l}0.0001 \\
(0.90)\end{array}$ \\
\hline Price to FFO & & $\begin{array}{c}0.003 \text { b } \\
(1.82)\end{array}$ & $\begin{array}{c}0.003 \text { b } \\
(1.94)\end{array}$ \\
\hline Adjusted R-square & 0.004 & 0.071 & 0.072 \\
\hline
\end{tabular}




\begin{tabular}{|c|c|c|c|c|}
\hline \multicolumn{5}{|c|}{$\begin{array}{c}\text { Table } 4 \\
\text { Descriptive Statistics for Subgroups }\end{array}$} \\
\hline Variable & $\begin{array}{l}\text { No Poison } \\
\text { Pill or } \\
\text { Staggered } \\
\text { Board }\end{array}$ & $\begin{array}{l}\text { Poison Pill } \\
\text { but No } \\
\text { Staggered } \\
\text { Board }\end{array}$ & $\begin{array}{c}\text { Staggered } \\
\text { Board but } \\
\text { No } \\
\text { Poison } \\
\text { Pill }\end{array}$ & $\begin{array}{l}\text { Poison Pill } \\
\text { and } \\
\text { Staggered } \\
\text { Board }\end{array}$ \\
\hline \multicolumn{5}{|l|}{ Governance Variables } \\
\hline Insider Block Ownership & 0.143 & 0.110 & 0.145 & 0.129 \\
\hline Outsider Block Ownership & 0.552 & 0.580 & 0.497 & 0.600 \\
\hline Operating Partnership Units & 0.652 & 0.444 & 0.686 & 0.750 \\
\hline \multicolumn{5}{|l|}{ Financial Variables } \\
\hline $\begin{array}{l}\text { Total Assets } \\
\text { (\$Millions) }\end{array}$ & 3,480 & 1,356 & 1,843 & 2,767 \\
\hline $\begin{array}{l}\text { Market Capitalization } \\
\text { (\$Millions) }\end{array}$ & 2,050 & 816 & 1,093 & 1,472 \\
\hline FFO to Assets & 0.020 & 0.016 & 0.016 & 0.015 \\
\hline Debt to Assets & 0.383 & 0.421 & 0.441 & 0.430 \\
\hline Price to NAV per Share @9\% & 1.07 & 1.05 & 1.02 & 1.16 \\
\hline FFO per share Growth & 0.080 & -0.052 & -0.063 & -0.034 \\
\hline Price to FFO & 9.72 & 10.11 & 10.05 & 9.61 \\
\hline
\end{tabular}




\section{Table 5:}

\section{Determinants of Cumulative Abnormal Returns By Subgroups}

This table reports the results from estimating a cross-sectional regression model to explain cumulative abnormal returns for each of the subgroup combinations of poison pills and staggered boards. We use a weighted-least-squares regression model to regress governance and financial variables on cumulative abnormal returns of individual stocks around the announcements of the Simon Property Group's hostiletakeover bid for the Taubman Centers, Inc. We use the standard deviations of the prediction errors derived from the market model as weights. $t$-statistics appear in parentheses under coefficient estimates.

b indicates statistical significance at the five percent level.

c indicates statistical significance at the ten percent level.

\begin{tabular}{|c|c|c|c|c|}
\hline Variable & $\begin{array}{l}\text { No Poison Pill or } \\
\text { Staggered Board }\end{array}$ & $\begin{array}{l}\text { Poison Pill but No } \\
\text { Staggered Board }\end{array}$ & $\begin{array}{l}\text { Staggered Board but No } \\
\text { Poison Pill }\end{array}$ & $\begin{array}{l}\text { Poison Pill and } \\
\text { Staggered Board }\end{array}$ \\
\hline Intercept & $\begin{array}{l}0.021 \\
(0.21)\end{array}$ & - & $\begin{array}{l}0.002 \\
(0.05)\end{array}$ & $\begin{array}{c}-0.095 b \\
(-2.45)\end{array}$ \\
\hline \multicolumn{5}{|l|}{$\begin{array}{l}\text { Governance } \\
\text { Variables }\end{array}$} \\
\hline $\begin{array}{l}\text { log of Market } \\
\text { Cap }\end{array}$ & $\begin{array}{c}0.0008 \\
(0.09)\end{array}$ & - & $\begin{array}{l}-0.005 \\
(-0.86)\end{array}$ & $\begin{array}{c}0.011 \text { b } \\
(2.47)\end{array}$ \\
\hline $\begin{array}{l}\text { Insider Block } \\
\text { Ownership }\end{array}$ & $\begin{array}{l}0.029 \\
(0.31)\end{array}$ & - & $\begin{array}{l}-0.050 \\
(-1.72) \\
\end{array}$ & $\begin{array}{c}0.146 \text { b } \\
(2.87)\end{array}$ \\
\hline $\begin{array}{l}\text { Outsider Block } \\
\text { Ownership }\end{array}$ & $\begin{array}{l}-0.067 \\
(-1.00)\end{array}$ & - & $\begin{array}{l}-0.005 \\
(-0.27)\end{array}$ & $\begin{array}{c}-0.0008 \\
(-0.05)\end{array}$ \\
\hline $\begin{array}{l}\text { Operating } \\
\text { Partnership } \\
\text { Units }\end{array}$ & $\begin{array}{l}0.018 \\
(0.84)\end{array}$ & - & $\begin{array}{l}0.012 \\
(1.39)\end{array}$ & $\begin{array}{c}-0.028 b \\
(-2.90)\end{array}$ \\
\hline \multicolumn{5}{|l|}{$\begin{array}{l}\text { Financial } \\
\text { Variables }\end{array}$} \\
\hline FFO to Assets & $\begin{array}{c}.553 \\
(0.36)\end{array}$ & - & $\begin{array}{c}1.269 \mathrm{c} \\
(1.73)\end{array}$ & $\begin{array}{c}-1.590 \text { c } \\
(-1.77)\end{array}$ \\
\hline Debt to Assets & $\begin{array}{c}-0.00007 \\
(-0.13)\end{array}$ & - & $\begin{array}{c}-0.0001 \\
(-0.25)\end{array}$ & $\begin{array}{c}0.0004 \\
(1.39)\end{array}$ \\
\hline $\begin{array}{l}\text { Price to } \\
\text { NAV@9.0\% }\end{array}$ & $\begin{array}{c}-0.00002 \\
(-0.05)\end{array}$ & - & $\begin{array}{c}0.00006 \\
(0.37)\end{array}$ & $\begin{array}{c}-0.00001 \\
(-0.88)\end{array}$ \\
\hline $\begin{array}{l}\text { FFO per share } \\
\text { Growth }\end{array}$ & $\begin{array}{c}-0.0001 \\
(-0.20)\end{array}$ & - & $\begin{array}{c}-0.0002 \\
(-0.73)\end{array}$ & $\begin{array}{c}0.0004 \\
(1.16)\end{array}$ \\
\hline Price to FFO & $\begin{array}{c}0.0005 \\
(0.11)\end{array}$ & - & $\begin{array}{l}0.002 \\
(0.89)\end{array}$ & $\begin{array}{c}0.006 \text { b } \\
(2.84)\end{array}$ \\
\hline $\mathrm{N}$ & 20 & 8 & 30 & 25 \\
\hline Adjusted $\mathrm{R}^{2}$ & -0.102 & & 0.048 & 0.444 \\
\hline
\end{tabular}

